\title{
'The School Was Closed, So When They Brought Me A Husband I Couldn't Say No': Exploring the Gendered Experiences of Child Marriage Amongst Adolescent Girls and Boys in Ethiopia
}

\author{
Guday Emirie $^{1} \cdot$ Nicola Jones $^{2} \mathbb{D} \cdot$ Meti Kebede $^{3}$
}

Accepted: 19 May 2021 / Published online: 29 June 2021

(c) The Author(s) 2021

\begin{abstract}
Child marriage is increasingly recognised as a development priority given its farreaching life-course and inter-generational consequences. Despite rapid progress, Ethiopia remains in the top five countries globally in terms of absolute numbers of married girls, with significant sub-national variation in the drivers and patterning of child marriage. This article applies a capabilities framing in a novel way to move debates beyond a sole focus on girls and a single modality of marriage. It explores the gendered experiences of child marriage amongst girls and boys in Amhara and Oromia regions, drawing on semi-structured interviews with 190 adolescents, 44 parents and 20 key informants from 2017 to 2020. The findings highlight contextspecific economic and gender norms drivers of adolescent-initiated and parentarranged child marriages, and their differential effects on girls and boys. The article concludes by discussing policy and programming implications in line with the 2030 Sustainable Development Agenda commitment to leave no one behind.
\end{abstract}

Keywords Ethiopia $\cdot$ Child marriage $\cdot$ Married girls $\cdot$ Married boys · Capabilities Gender norms · Adolescents

\section{Résumé}

Le mariage d'enfants est de plus en plus reconnu comme une priorité de développement tant les conséquences sont profondes sur la trajectoire de vie et sur les différentes générations. En dépit des progrès rapides, l'Éthiopie figure toujours parmi les cinq pays au monde ayant le nombre absolu le plus élevé de filles mariées, avec d'importantes variations sous-nationales en ce qui concerne les déterminants et les

Nicola Jones

n.jones@odi.org.uk

1 Addis Ababa University, Addis Ababa, Ethiopia

2 ODI/GAGE, London, UK

3 GAGE Ethiopia, Addis Ababa, Ethiopia

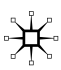


motifs du mariage d'enfants. Cet article applique un cadre axé sur les capacités d'une façon novatrice afin de dépasser la focalisation sur les filles uniquement, et sur une seule modalité de mariage. Il explore la dimension sexospécifique des expériences du mariage d'enfants chez les filles et les garçons dans les régions d'Amhara et d'Oromia, en s'appuyant sur des entretiens semi-directifs avec 190 adolescent.es, 44 parents et 20 informateur-rices clés entre 2017 et 2020. Les résultats mettent en évidence les déterminants économiques et sexospécifiques liés au contexte de mariages d'enfants initiés par les adolescent-es et arrangés par les parents, ainsi que les différents effets sur les filles et sur les garçons. L'article aborde les implications politiques et programmatiques en guide de conclusion, conformément à l'engagement de ne laisser personne de côté du Programme de développement durable à l'horizon 2030.

\section{Introduction}

Over the past decade, the visibility of child marriage as a human rights violation has increased significantly, and its eradication is included in target 5.3 of the Sustainable Development Goals (SDGs). There is a growing consensus that child marriage curtails adolescents' educational and economic opportunities, puts married girls at heightened risk of intimate partner violence and at risk for early, frequent and highrisk pregnancies and pregnancy-related injuries, such as obstetric fistula (Yaya et al. 2019). The risks are also inter-generational: children of child brides face greater infant morbidity and mortality risks than those born to mothers who have reached adulthood (Raj 2010).

Although the problem is global, the highest rates of child marriage are found in South Asia and in sub-Saharan Africa. Ethiopia remains in the top five countries globally for child marriage, with an estimated two million child brides, ${ }^{1}$ but the country has been lauded for having one of the highest rates of annual decline since 2010 relative to other Eastern and Southern African countries (UNICEF 2018). ${ }^{2}$ In the mid-2000s, approximately $50 \%$ of Ethiopian girls married before their 18th birthday, but by 2016 the rate had fallen to $40.3 \%$ (Central Statistical Agency (CSA) and ICF 2017). Analysts attribute this to rapid progress in girls' education, investments in awareness-raising about the legal age of marriage (as per the 2000 Revised Family Code), and improved systems for reporting violators (Jones et al. 2018a, b; Wodon et al. 2018). National figures, however, hide considerable regional variation in the drivers and patterning of child marriage in Ethiopia, thereby hindering context-tailored interventions. For example, amongst women aged 20-49, the median age at first marriage ranges from 16.2 years in Amhara to 18.2 years in Southern Nations, Nationalities and People's Region (SNNPR) (CSA and ICF 2017). National averages also mask significant variation by gender: on average, $40.3 \%$ of girls are

\footnotetext{
${ }^{1}$ Girls Not Brides estimates that Ethiopia has 2,104,000 child brides, based on data from the EDHS. https://www.girlsnotbrides.org/child-marriage/ethiopia.

2 Ethiopia, with a $4.2 \%$ annual decline, is ranked second behind Rwanda (6.9\%) out of 19 eastern and southern African countries (UNICEF 2018).
} 
married before age 18, but just $1.7 \%$ of boys (Gaston et al. 2019). However, disaggregated data show considerable regional variation amongst rates of married boys; Muthengi Karei and Erulkar (2010) use Ethiopia Demographic and Health Survey (EDHS) data to estimate that up to $18 \%$ of boys in Amhara were married before age $18 .^{3}$

This article explores the gendered experiences of child marriage amongst adolescent girls and boys in Ethiopia, focusing on the contrasting drivers of adolescentinitiated and parent-arranged child marriage to understand how the context-specific interplay of economic factors and discriminatory gender norms affects girls and boys differently. This is an area which has received very limited research attention globally (Gaston et al. 2019; Biswas et al. 2020), and even less in the sub-Saharan African regional and Ethiopian contexts (Amoo et al. 2018), notwithstanding the call in the African Charter for the Rights and Welfare of the Child for the prohibition of 'child marriage and the betrothal of girls and boys' (Article 21: 2). We draw on baseline and midline qualitative data collected for the Gender and Adolescence: Global Evidence (GAGE) study from 2017-2018 and 2019-2020 in Amhara and Oromia regions, both identified by the Ethiopian government and UNICEF as child marriage 'hotspots', to explore the diverse drivers and patterning of child marriage amongst adolescent girls and boys.

The article is organised as follows: the "Conceptual Framing" section presents our conceptual framework, "The Ethiopian Context" section provides an overview of the Ethiopian context, the "Methods" section introduces the methodology and sample and the "Findings" section presents key findings. The "Discussion" section discusses the significance of the findings in terms of the broader literature as well as for policy and programming priorities, including with regard to commitments enshrined in the 1990 African Charter for the Rights and Welfare of the Child and in the 2030 Sustainable Development Agenda and the "Conclusion" section concludes.

\section{Conceptual Framing}

As child marriage has risen up the international development policy agenda, there has been robust debate about how to conceptualise the practice and its underlying drivers, and in turn inform change initiatives. Some frame it as a public health issue, given heightened risks of maternal and infant morbidity and mortality (Bankole et al. 2007; de Groot et al. 2018), whilst others apply a human capital lens, focusing on lifelong deficits in terms of health, education and future earnings (Wodon et al. 2018; Raj et al. 2019). Tackling child marriage can not only strengthen gender equality across the life course, but also contribute to sustainable development more broadly, given the links between child marriage and poverty, hunger, food insecurity,

\footnotetext{
3 The EDHS reports retrospectively by asking respondents aged 20-49 years what percentage were married before 18 years, but is not asking adolescents in real time. Figures on the percentage of boys married as children have only recently begun to be published systematically (Gaston et al. 2019) and using the most recent 2016 EDHS only.
} 
age- and gender-based violence (including intimate partner violence) (Girls Not Brides 2017). Others still have adopted a human rights violation framing, calling for legal reforms and law enforcement (Arthur et al. 2018; Santelli et al. 2018) to eradicate culturally embedded 'harmful traditional practices' (le Roux et al. 2017).

Whilst each of these perspectives highlights important dimensions of child marriage and potential entry points for change, given the diversity of child marriage practices that involve varying degrees of agency (i.e. adolescent-initiated vs arranged marriage), we argue that a capabilities framing better captures this spectrum of practices for several reasons (GAGE Consortium 2019).

First, a capabilities approach, as championed by Sen (2008) and Nussbaum (2011), explores the kinds of assets (economic, human, political, emotional and social) needed to expand individuals' capacities to become purposive actors and achieve valued ways of 'doing and being'. This framing emphasises investment in an individual's skills, knowledge and voice. Accordingly, whilst arranged marriage clearly undermines a young person's skills and voice, an adolescent-initiated marriage could - in the context of constrained choices_-provide a pathway to a socially valued adulthood, or at least an escape from an intolerable home life. To promote changes in norms and practices around child marriage, a capabilities framing would therefore suggest investing in young people's knowledge, skills and voice so as to support alternative valued ways of 'doing and being'.

Second, a capabilities lens encompasses not only the physical, economic and educational competencies emphasised in human capital development theories but also the centrality of an individual's psychosocial well-being and their ability to exercise agency and voice in setting and achieving their own goals (Sen 2008). Through this lens, arranged marriages not only result in human capital deficits but also prevent young people exercising agency and voice in decisions that affect their lives. In the case of adolescent-initiated marriage, whilst the initial decision to marry as a minor may constitute an expression of agency, a focus on multidimensional capabilities prompts an investigation of the quality of the ensuing marital relationship and the extent to which adolescent girls can achieve psychosocial well-being and exercise voice and agency.

Third, more recent thinking around the capabilities approach critiques the emphasis on individual capabilities for underestimating how individuals' actions are embedded in cultural and social norms (Stewart 2005; Ibrahim 2006). Rauschmayer et al. (2018) argue that collective processes play a significant role in values, goals, capabilities and functionings, and in enabling vulnerable groups to demand legal reforms, services and support. To overcome this, some scholars have theorised 'collective capabilities', generated by collective agency and the pooling of personal responsibilities (Ibrahim 2006). Applying this to adolescents, supporting their empowerment as a group may make their specific needs more visible-including the need to be supported to choose pathways beyond marriage and parenthood.

Finally, whilst studies on gender norms have tended to focus on their negative impacts on girls and women (George et al. 2020: Harper et al. 2018), there is increasing evidence of how traditional norms of masculinity that uphold gender inequalities can also have harmful effects on boys and men (Connell and Messerschmidt 2003). Whilst historical and anthropological studies have shown that masculinities 
are socially constructed and shaped by local culture, social organisation and economic contexts (Connell 2003; Messerschmidt 2019), 'hegemonic masculinity' currently embodies the most honoured way of being a man and 'ideologically legitimates the global subordination of women to men' (Connell and Messerschmidt 2005 , p. 832). Typical traits of hegemonic masculinities include power, aggression, control, repression of emotions and risk-taking. Marriage can constitute part of the 'script' of hegemonic masculinity_-seen most clearly in cultures which value marriage between older male partners and child brides (Clark et al. 2006). However, due to dominant understandings of masculinities, boys may also feel pressured to marry as adolescents, to demonstrate their 'adulthood', to secure property inheritance or to continue the family line (UNICEF Regional Office for South Asia 2018). Doing so may harm them, affecting the quality of their relationship with a younger spouse or bringing heavier responsibilities as family provider and a young parent. There is also space to resist these norms, depending on their strength in a given community. In this regard, Cislaghi et al. (2019) hypothesise that norms may be experienced as 'obligatory', 'appropriate', 'tolerated' and 'possible'. The findings in this paper are interpreted with this framing in mind.

\section{The Ethiopian Context}

Ethiopia-Africa's second most populous country-is characterised by a high degree of ethnic and religious diversity and an ethnic federalist political structure, with regional states organised around ethnic and linguistic groupings. The complexities of marriage practices and norms must be understood within this diverse context. The Revised Family Code of 2000 makes marriage before the age of 18 years illegal, although it has not been ratified by all regional states. The 2019 National Costed Roadmap to End Child Marriage and Female Genital Mutilation and Cutting, reflecting the Ethiopia government's proactive approach to tackling child marriage, sets out a vision to eliminate these harmful practices by 2030 (Ministry of Women, Children and Youth 2019).

\section{Trends in Child Marriage over Time}

The most recent Ethiopia Demographic and Health Survey (EDHS) 2016 shows that of young adults aged 20-24 years, $40.3 \%$ of women and 5\% of men were married before the legal age of 18 (CSA and ICF 2017). According to UNICEF (2018), this reflects an annual average rate of decline of $4.2 \%$ over the past decade. Disaggregating by age cohort, the percentage of girls married by age 15 shows a remarkably fast decline by around 60\%: of young women aged 20-24, $14.1 \%$ were married by age 15 , compared to $5.7 \%$ of girls aged 15-19 years. ${ }^{4}$ Amongst boys, the change is less dramatic and there are more data gaps; whereas $9.1 \%$ of men aged 25-59 years had

\footnotetext{
${ }^{4}$ Contemporaneous data are possibly less accurate given reporting biases because of fears of prosecution if found to be flouting the law by marrying before age 18 .
} 
married by age 18, amongst those aged 20-24 the figure was 5\% and no figure for boys aged 15-19 years married by age 15 .

\section{Regional Diversity of Marriage Patterns}

Given Ethiopia's ethnic and religious diversity, it is unsurprising that patterns and progress vary considerably across regions. Comparing EDHS data from 2005, 2011 and 2016, the median age at first marriage for women aged 20-49 years has increased in all regions except Afar and Harari. For men aged 20-49 years, the median age at first marriage ranged from 22.5 years in Amhara to 24.8 years in Somali region.

However, EDHS data does not report down to zone or woreda (district) level. This is problematic given the large population of some regions (e.g. Oromia was estimated to have 37.3 million people and Amhara 21.8 million in 2019) ${ }^{5}$ and because of the diversity within regions of ethnicities, religions, cultures and livelihoods-all of which shape marriage practices.

Research by the Overseas Development Institute (ODI), Ministry of Women, Children and Youth Affairs and the National Alliance to End Child Marriage identified the top 40 'hotspot' woredas for child marriage, challenging previous understandings about the areas where the practice was most widespread (see Jones et al. 2016a, 2016b). Amongst girls aged 10-14 years, and only in Oromia, for example, the proportion who were married at the time of the most recent census ranged from $15.2 \%$ in East Hararghe zone to 6.2\% in Bale zone. Amongst girls aged 15-17 years in Tigray, rates ranged from $37.8 \%$ in Western Tigray to $9 \%$ in Eastern Tigray. Understanding these variations is critical for shaping programming and deciding where to prioritise scarce resources.

\section{Types of Marriage Practices}

In Ethiopia, there are three main types of child marriage: those arranged by parents, those carried out by abduction and marriage by choice. Although practices are changing rapidly, many parents - predominantly in rural areas-continue to arrange their daughters' marriages, at any time during childhood (Erulkar and Muthengi 2009; Emirie et al. 2017; UNICEF 2018). ${ }^{6}$ In the case of promissory marriage, involving a verbal promise by parents to marry their daughter to a specified partner, marriage can be arranged even before the child's birth to cement ties between the two families (or within families, in the case of Afar, where absuma-marriage to a maternal cousin-is widespread). Whilst arranged marriages have, in the past decade, become less common (Jones et al. 2014), in a national sample of married girls

\footnotetext{
5 See CSA (2013) population estimates.

${ }^{6}$ UNICEF (2018) highlights that 48\% of 20-24-year-old women who married as children are from rural areas, and only $16 \%$ from urban areas.
} 
aged 12-24 years, 70\% were in an arranged marriage, as were nearly all of those married before age 15 (Erulkar et al. 2010).

Rates of arranged marriage also vary by region and religion. In Amhara, for example, nearly $95 \%$ of married girls were in an arranged marriage, and Orthodox girls were more likely to be so than their Muslim peers (81\% versus 62\%) (Erulkar et al. 2010). Marriage by abduction is not uncommon, but appears more common in southern areas, which have traditionally had bride price arrangements (giving cattle or money to the bride's family) (Erulkar et al. 2010). Some young men who lack the money to marry may, with help from friends and family, plan to abduct a young woman and then rape her (Boyden et al. 2013), hoping that the girl's family will then allow him to marry her (in the knowledge that marriage prospects for a girl who is no longer a virgin are very limited, due to conservative gender norms) (Jones et al. 2018a, b). However, marriage by 'abduction' can sometimes be consensual; young couples agree to stage an abduction so that elders from both families will be compelled to agree to the union (Jones et al. 2014).

Where marriage takes places in late adolescence or early adulthood, especially in urban areas, marriage by choice (or arranged marriage based on choice) is becoming more common (Jones et al. 2014). In some areas, partners are eloping to circumvent an arranged marriage, though in Oromia, for example, Young Lives respondents believed that this was undesirable as it circumvents tradition and leaves girls more vulnerable to divorce (Boyden et al. 2013).

\section{Methods}

We now turn to a discussion of our research methods informed by qualitative research reporting standards (O'Brien et al. 2014). This article uses a qualitative research approach with an exploratory research design. It draws on two rounds of semi-structured individual and group interviews with adolescents $(n=190)$, parents $(n=44)$ and district and community-level key informants $(n=20)$ to explore what works to support the development of adolescents' capabilities (those aged 10-19 years). Data were collected between late 2017 and early 2018, and again in late 2019 and early 2020, in two zones previously identified as child marriage 'hotspots'-South Gondar (Amhara region) and East Hararghe (Oromia). Research by Jones et al. (2016a) using 2007 census data had found that these zones ranked 6th (for girls married aged 10-17 years) and 1st (girls aged 15-17 years) respectively in their regions, and 12th and 5th (for those aged 15-17 years) nationally.

Adolescent respondents were purposefully selected from a larger quantitative sample (see Jones et al. 2018a, b), using two cohorts: younger adolescents (10-12 years) and older adolescents (15-17 years) at baseline. Where married adolescents were already included in the main sample, these were included in the qualitative sub-sample; however, in communities where married adolescents were not included (typically due to concerns about the illegality of child marriage), researchers used a snowballing technique to identify married adolescents. For an overview of the sample, see Table 1. 


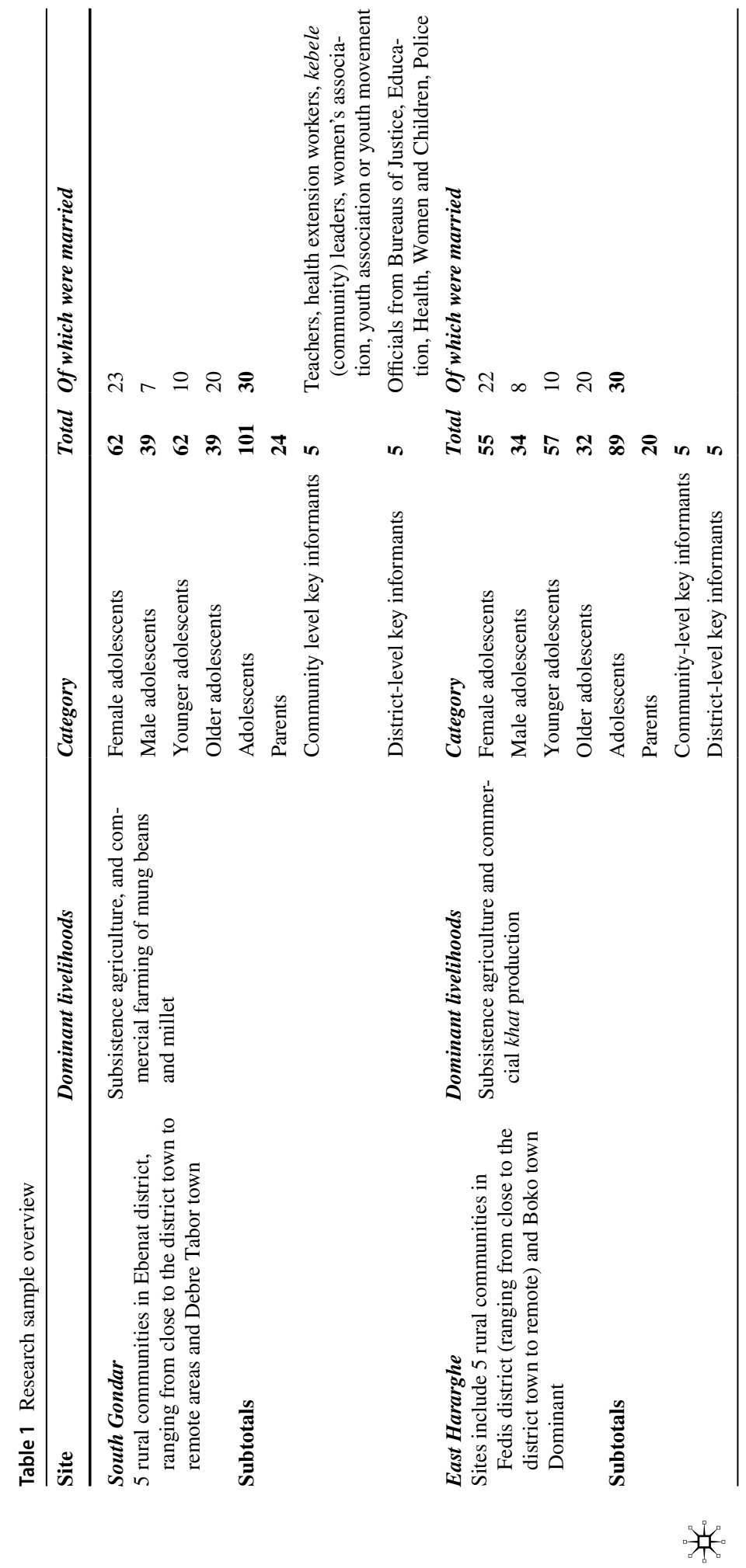




\section{Research Ethics}

Research ethics approvals were obtained through the ODI Research Ethics Committee and the Regional Ethics Boards of the Ministry of Health in Ethiopia. Researchers were trained on how to interact appropriately and responsively with adolescents, including married adolescents, and how to ensure privacy and confidentiality (including assigning each interview a numerical code and uploading recorded interviews in a password-protected folder daily). Verbal assent was obtained from adolescents under 18 years, and verbal consent was obtained from caregivers and husbands and/or in-laws in the case of married girls.

\section{Research Process and Instruments}

Interviews were carried out face-to-face by local researchers who spoke Afaan Oromo and Amharic as appropriate; researchers were from the same region and of the same sex as the adolescent respondent to increase trustworthiness.

Qualitative research tools included individual object-based interviews, groupbased body mapping exercises and community mapping (see Jones et al. 2018a, b). The second round of data collection included two tools designed to explore child marriage: the 'marriage chain', exploring decision-making around marriage and marriage experiences amongst married adolescents; and 'marriage pairs', investigating attitudes and norms amongst 'gatekeepers' such as parents and husbands. Key informant interviews were carried out with kebele leaders, health extension workers, teachers, police, local religious leaders and officials from the Bureaus of Women's Affairs and Justice.

\section{Data Analysis}

For the qualitative research component, preliminary analysis took place during daily and site-wide debriefings with the research team, and findings were used to develop a thematic codebook. All interviews were transcribed and translated into English by native speakers of the local language, then coded by a team of experienced coders, including from Ethiopia, using MAXQDA software. Once coded, the authors employed a thematic analytical approach, triangulating findings from the different types of respondents and interview types.

\section{Findings}

Drawing on the capabilities and social norms framing outlined earlier, our findings discuss similarities and differences between girls' and boys' experiences of marriage pressures and marital relationships. We explore adolescents' individuallevel capabilities and the role that family level factors play in shaping these, and 
adolescents' collective capabilities (both in terms of norms around child marriage and public institutions that mediate adolescents' opportunities to realise their full human potential).

\section{Individual-Level Capabilities}

Based on our capabilities framing of child marriage, understanding individual adolescents' access to and control over resources is critical. Our findings point to considerable diversity - by geography and, to some extent, gender-in terms of individual agency in deciding on a marriage partner. In East Hararghe (Oromia), even very young adolescent girls emphasised that the marriage was their choice, facilitated by shegoye (a cultural dance) that brings girls and boys together until late into the night or early morning, sometimes for weeks and months. For example, a 15-year-old married girl explained her choice of partner at age 12:

I started playing shegoye when I was 10. I played it for two years before I got married. I had a boyfriend that I used to hang out with and play shegoye with. But the guy who married me came in between, we agreed to marry and I ran away with him. My relationship with my shegoye mate broke up at that time. When we met and talked, he [my future husband] put aside his girlfriend and I also dumped my partner that I had thought I would marry.

Married adolescent boys also highlighted that the decision to marry when they did was theirs. A 17-year-old boy explained that his approach to selecting a partner had been deliberate, facilitated by a local broker he contacted, without his parents' involvement:

I went to different neighbourhoods before finding her in [local neighbourhood name]. When we went there, girls gathered, many girls were brought to the house... I pay the owner money, 500 birr, if I find a girl I marry amongst the ones she brought... I went to three neighbourhoods and made the decision after the third one.

Whilst turning to marriage brokers is increasingly common in East Hararghe, others rely on meeting a future partner at shegoye or arusa ${ }^{7}$ (friends' honeymoon ceremonies). Others still solicit the help of their friends to pressure a girl they like into agreeing to marriage.

Whilst there were some exceptions in our sample in South Gondar (Amhara), the level of individual agency, especially amongst girls, was considerably restricted-by parents and, in some cases, grandparents. A 12-year-old married girl summed up her experience succinctly: 'The school was closed, so when they brought me a husband, I couldn't say no.' Similarly, an 11-year-old married girl explained:

\footnotetext{
7 The arusa or honeymoon ceremony involves friends joining the bride and groom for multiple evenings of dancing and celebration, and this provides a venue for adolescents to meet potential partners.
} 
It was my grandfather who decided to get me married at my young age... My grandfather even threatened my parents that he would curse them unless I got married to his stepchild... He began preparing a wedding before getting my parents' response and then my father had no option and was forced to accept the marriage request...

Such cases of denied agency were more common amongst adolescent girls in our sample but there were cases amongst boys, albeit in later adolescence. An 18-year-old who was married off a year ago described his experience:

I was not aware about the marriage arrangement until the eve of the wedding date... I told my father the marriage was like an abduction... I asked them to allow me to decide to marry whom I chose. But my father argued that she is from a well-respected and wise family.

Our findings also suggest that respected community figures, especially religious leaders, can influence norms around early marriage. As a 30-year-old mother explained, her daughter (then aged 12) was married last year to a deacon [in the Ethiopian Orthodox Church] 'because deacons marry girls who are young. Her father allowed the marriage. We were told that deacons get married to young brides. The father gave her away. I could not stop him.' In such cases, the married girl may stay with her parents or in-laws for a year or two, with an oral or written contract (giyad) protecting her from a sexual relationship with the husband until she is deemed 'old enough'-typically with the onset of menarche (see also Jones et al. 2018a, b).

Our findings highlight a second set of key factors that shape adolescents' vulnerability to child marriage: the breakdown of the family unit, whether due to divorce, intra-household violence, or death of a family member (especially the breadwinner), and subsequent problems in relationships with step-parents. Of note here is that these factors appeared to affect girls and boys alike. One girl aged 13 from South Gondar recounted that when her stepmother announced she was to marry the very next day, she did not resist as her relationship with the stepmother was fraught:

My stepmother told me that they were giving me for marriage. I did not cry or try to run away. I kept quiet, what else can I do? I had been fighting a lot with my stepmother and getting married would mean moving to a new locality. I was sad to leave my father, but I was happy to leave my stepmother, to get away.

In another case, a father who agreed to marry his daughter at age 16 reported feeling pressure to accept the marriage offer not just because the prospective groom was a deacon who is under pressure to marry a young bride (see above), but also because he empathised with the challenges the young man faced with his stepmother:

His [the groom's] mother had died, and it was very hard for him to live peacefully with his stepmother... We feared he may lose his chance to serve in the church because he didn't find enough food at home as he couldn't live peacefully with his stepmother. 
Intra-household violence (against the adolescent or his or her mother) also emerged as an important driver of early marriage, as marriage offers a culturally acceptable exit from an intolerable situation. This account by a 45 -year-old father from East Hararghe about his violent behaviour towards his daughter helps explain her decision to elope at age 11:

I beat the elder girl when she played with boys....She was injured... She never went out at night after that... I wasn't happy with her because she terminated her schooling at grade 6 after that. I had wealth at that time; I was running my own business. I was trying to kill her. She disappeared from this area for two weeks. I brought her back through the local militia. Then she went to Boko town again and started living with a boy. She was 11 years old.

Serious illness or death of a parent was another common reason for early marriage. Some parents pressured their children to marry whilst they could still enjoy the wedding ceremony, and wanted the comfort of knowing their children were successfully married before their death. A father who allowed his daughter to marry at age 13 explained that the groom's father had initiated the wedding because of fears related to his ill-health: 'He wanted to be happy when his son got married. The boy got married to make his father happy. The couple did not know each other when they got married.' In cases where the family breadwinner had died, early marriage was seen as a way of alleviating financial strain by either bringing in extra labour to the household or reducing the number of family members to provide for.

\section{Adolescents' Collective Capabilities}

\section{Social Norms Around Marriage and Their Role in Shaping Adolescents' Collective Capabilities}

Our findings underscore that social norms and practices around marriage (including timing) are a key driver of child marriage, especially for girls but also for boys in some communities. Whilst the dynamics are distinct, our research indicates that for arranged and adolescent-initiated child marriage alike, social norms play a key role in shaping adolescents' collective capabilities by defining what is 'appropriate' behaviour (Cislaghi et al. 2019) at this juncture in the life course.

Norms around bride price were a major distinguishing factor between marriage practices in the two study areas. Our findings underscore that the exchange of gifts between the two families remains a dominant practice in South Gondar and is a key reason for the persistence of arranged marriages. A 40-year-old father who married off his daughter at age 15 explained that the livestock and land he had contributed had been a critical factor in shaping the timing of the marriage: 
We gave them gifts [endowments]. I gave one ox and his father also gave one ox...In total we gave them six cattle as bride price. We also gave them six temad [0.25 hectares] of land. Now they farm sesame and maize.

Parents often agree to a union for their child when they have secured sufficient wealth to contribute and when a favourable offer (from the groom) emerges, as both factors together will ensure a sustainable livelihood for the couple. ${ }^{8}$

Some married boys in South Gondar, where arranged marriage is common, explained that they felt considerable pressure to marry, sometimes from family members wanting to cement an alliance with another well-respected family. As a 19-year-old boy who had married 2 years ago noted:

I was told about her but I didn't know the details of her family background... When I first saw her at the marketplace, I was not happy. After I saw her physical appearance, I asked them why they chose such a child. But I was forced to accept so as not to waste the resources prepared for the wedding, I was advised to get divorced if I didn't like to maintain the married life... She was 10 years old. We got married two years later when she was 12 .

In other cases, pressure to marry stemmed from parents devaluing education and wanting sons to help with farming. Adolescent boys highlighted that norms around respect for parents and elders meant they had little scope to refuse, as an 18-year-old married boy explained:

I refused to go to the girl's home because I thought it is a kind of forced marriage... But then I was convinced by my family that I had to accept their proposal. I got married because of my parents' influence, and if I had changed my mind it would have been considered as deviant, which is unacceptable and disgraceful.

By contrast, because of rising poverty and land scarcity in East Hararghe, parents reported that at best they could hope to provide a house in the family compound for their sons. This meant they have a diminishing role in influencing their sons' marriage (compared to previous generations), and partly explains why adolescent-initiated marriages (often facilitated by local brokers or casually, by friends) are increasingly the norm. A 70-year-old father reflected that:

Nowadays parents can't do much... Friends tell a girl that someone is in love with her and wants to marry her... The groom pays the friends... He tells them to convince the girl... If he forces her to live with him or abducts her, you [the father] take back your girl. But if she consents to go and live with him, there is nothing that you can do. If you take her back, she will say, 'I am in love with him'. So, as much as you can, you advise your girls at home.

\footnotetext{
8 This practice of parental endowment at the time of marriage in Amhara is locally known as 'equal matching'; girls from better-off households are more likely to marry early because their parents' resources attract would be husbands or in-laws.
} 


\section{Peer Pressure}

Peer pressure played a significant role in adolescent-initiated marriages (for girls and boys) and arranged marriages (for girls). Married girls in both sites reported that peer pressure had played a key role in timing of marriage, with a 15 -year-old from East Hararghe noting:

I felt happy with the timing [at age 13] because... it was due time for me. Older friends had already got married. I had also reached puberty by then. Thus, I was seeking to get married.

For older girls, peer pressure often became less benign, with several reporting feeling compelled to marry to avoid insults and out of fear of fewer options in terms of choice of partner (i.e. only divorced or older men). As an 18-year-old boy from East Hararghe explained:

Nobody will marry her if all her peers have got married at a younger age. She may get a divorcee. Youngsters are not interested in her since she has grown older... Males want to marry females that are younger than themselves.

In some cases, our findings are aligned with understandings of hegemonic masculinities as an expression of power, control and violence, and indicate that peer pressure around relationships and marriage also involves culturally sanctioned threats of violence (or actual violence) perpetrated by boys and young men. A 20-year-old man highlighted how norms around dominant masculinity can contribute to sexual violence where adolescent girls do not submit to a marriage request:

[If she turns down his request for marriage], he may seek revenge against her when he has lost hope about their relationship or when he knows that she will be with others, he may revenge her forcefully... He will decide to rape her or to spoil her life because he waited for her a long time without any profit for his life.

A 16-year-old orphaned girl from who had married at 14 noted that she was often threatened with sexual violence, which pushed her into early marriage: 'I used to be threatened to face harm as I hadn't had a father who could take care of me... The threat was that I would be exposed to rape and have an unwanted pregnancy...'

In East Hararghe, some respondents revealed that whilst participation in shegoye is ostensibly by choice, boys often pressure girls psychologically or physically (through violence) to take part. As a local youth leader noted:

Some go [to shegoye] based on their interest. Some are forced to go there. Boys send other girls to bring them to the dance place... They have their own rules. They will not involve the girl who refused to go to the dance in any youth activities. Then to avoid this, the girls try to find ways to sneak out of the house and join the dance to avoid the rejection or discrimination by the youths. They try to lure her to go out and then beat her... with sticks and the leaves of a plant that makes you itch. She will not tell her parents. If she tells, 
she will be penalised by the youths... They beat her at night, not during the daytime.

Whilst boys in South Gondar mentioned pressure from parents and elders, some in East Hararghe emphasised the role of peer pressure. As an 18-year-old boy who married at age 17 explained: 'The youngsters compete with one another in getting married. They have no other things to compete against each other in. They fail to respect the guidance of kebele authorities and religious leaders for this reason.'

Another explained that financial pressures play a role; friends support one another with money during wedding preparations, so it is hard to turn down peers offering such support. As another 18-year-old boy who married at age 17 noted:

In this area it is common that people support one another financially at the time of marriage... They advised me that they would support me as we had been doing for others previously... They advised me to get married by giving me examples of my peers who got married.

\section{The Role of Public Institutions in Shaping Adolescents' Collective Capabilities}

Limited access to post-primary education, and poor-quality education, were mentioned as drivers of arranged and adolescent-initiated marriages-for girls in particular but also for some boys. An 18-year-old girl from East Hararghe, now separated but who married at age 15, noted: 'I hated schooling for I couldn't perform in my education. I couldn't even identify letters and develop the skill of reading... The teachers don't teach properly. They just write notes for us on the blackboard and leave...' Married girls in our East Hararghe sample also reported that few girls stayed in school beyond grade 8 because of distance from secondary schools and lack of role models. As a divorced 12-year-old girl (in grade 8 at the time of her marriage) explained:

I didn't expect to go to secondary school... My interest at the time was to enjoy shegoye and I gave no weight for education. [If I had continued my education] I wouldn't have had friends with whom I could go to the next school level, for all youngsters drop out at that level [grade 8]. Secondly, my interest in education dwindled drastically when I began to attend shegoye.

A 17-year-old explained that his decision to marry early reflected the few alternative pathways available to young people in remote rural communities:

The school [here] teaches only up to 8th grade. One needs to move to the town to attend secondary school... In my case, life has been difficult due to my family's economic challenges... Managing going to school in those circumstances was difficult for me and I resorted to marriage as a result.

This view was reinforced by a 19 -year-old married boy who had previously lived in a more urban environment:

Where I used to live, because the community is educated, girls marry after 18 and boys marry at age 20 or older. But here, girls start from age 15 and boys 
even before 16 marry... The quality of education here is too low and there are children who joined grade 9 and cannot read in Afaan Oromo... Since there is no one successful in their education from this locality who can be a role model, parents encourage their children to do household chores and farming whilst they are too young.

In South Gondar, age was also a factor. Most of the very young married girls there had not had any schooling. In remote rural villages, girls reported there being no school nearby and that their parents had assigned them full-time herding responsibilities, leaving little scope for a different path. As a 12-year-old married girl explained:

In childhood we were looking after goats. What else should we know? Our mothers and fathers did not send us to school... It is only after I got married last year that I have seen a school... It is after we married a husband that we saw the town. I did not know anything about school.

Yet amongst girls who married in later adolescence, some reported having been in school at the time of their marriage, and whilst this was not a protective factor against arranged marriage, they had tried (with varying degrees of success) to negotiate to continue their education post-marriage. A 15-year-old girl attending grade 6 noted that whilst her peers had initially criticised her for allowing marriage to interfere with her education, she had negotiated with her husband to continue studying:

They [my friends] spoke to each other after I returned to class following my wedding and at first my friends were not happy and blamed me for accepting the marriage, as they thought it could affect my education. I kept quiet... But my husband is willing to assist me until I finish school.

However, another 15-year-old girl, who had also tried to negotiate with her husband to continue her education, explained that she had been unsuccessful due to social norms that preclude girls combining marriage and education: 'I tell my inlaws that I would be happy if I could go to school... and I tell them that my husband is not allowing it... but they say it is because it is not easy for girls to combine schooling with other things.'

The broader legal and policy environment—on adolescents' rights in general and child marriage in particular-affects adolescents' opportunities to realise their full capabilities. Many of the respondents in our sample knew that the Family Law proscribes child marriage, although some incorrectly assumed that 15 years and above was permissible. However, even in communities with widespread awareness about the legal age limit, practice still deviated due to gender norms (already discussed), limited reporting channels, poor law enforcement and the dearth of role models pursuing alternative trajectories.

Two young men, both of whom married girls aged 15, highlighted the general sense of impunity around child marriage, with one commenting: 'We received training against early marriage in the school and in the church too... But there is not any kind of punishment when you marry a girl before 18 years.' This highlights the need for an approach that tackles dominant masculinities and considers the harms done to 
adolescent girls through perpetuation of child marriage practices. Others reported that community and religious leaders are often complicit, carrying out ceremonies (ritual and legal) without asking about age or confirming the girl's consent. An 18-year-old married girl from Melke noted that authorities are not proactively tackling under-age marriage: 'The sheik did not ask any questions. He didn't ask about our ages... In fact I was not there [when the marriage arrangement was worked out]... I was out collecting water. No one asked me whether I agreed to it.' Even in communities where the local youth movement (qerroos and qarrees) ${ }^{9}$ and religious leaders were trying to tackle shegoye, adolescents explained that it was to reassert parental control and improve school performance rather than prevent child marriage. As a 17-year-old married boy explained: 'The qerroo and the religious fathers have been trying to stop shegoye... They propagate that the youngsters who participate in the dance are defying sharia and should refrain from the behaviour.'

Fear of prosecution was not always a deterrent for parents organising an arranged early marriage. For example, a 30-year-old mother who had attempted to marry off her 12-year-old daughter explained that she had been detained and jailed, but had persisted with the marriage afterwards due to community pressures:

One of my girls got me detained... She said, 'My mother is going to force me to get married without my interest. I want to attend school.' I was detained and jailed. But afterwards she got married at my mother's house. My brothers and sisters prepared the ceremony whilst I was in jail... I didn't tell her that she is going to get married... I did that without her consent...

Similarly, a 15-year-old girl noted that whilst some teachers were trying to intervene to prevent child marriages, adolescent-initiated marriages often continued:

There are teachers who try to interfere and stop marriage to prevent girls from dropping out. Last year, for example, teachers punished students who were planning to elope with each other. They released the partners after confining them to the office for four hours. Unfortunately, however, the students got married with each other after being released...

\section{Discussion}

Using a gendered capabilities conceptual framing, this article has highlighted that adolescent girls are more vulnerable to arranged child marriages that threaten the development of their individual capabilities, including education and learning (Raj et al. 2019), economic empowerment (Wodon et al. 2018) psychosocial well-being and bodily integrity (Kidman 2016). This is especially so in contexts where secondary school options involve travel outside the community (which is considered risky by parents) and where there are few female role models who have exercised agency

\footnotetext{
9 These are the Afaan Oromo terms for male and female adolescent/youth activists, respectively, which have emerged over the past 3 years and played a major role in the country's political transformation.
} 
to choose a path other than marriage and motherhood. Girls are also vulnerable in communities where 'gatekeepers' of traditional gender norms (including parents, peers, community elders and religious leaders) are unchallenged by champions of change, such as girls' club teachers, health extension workers or NGO implementers of adolescent empowerment and safe space programmes. In communities where child marriage tends to be adolescent-initiated, girls face significant peer pressuresometimes violently enforced in line with concepts of hegemonic masculinity (see Connell and Messerschmidt 2005) — to take part in 'shegoye', the cultural dance that encourages young people to find a marriage partner often at the cost of their schooling.

An important contribution of this article to the broader evidence base is its inclusion of boys (on which there is very limited research, see, e.g. Biswas et al. 2020). Our findings show that boys are at much lower risk of child marriage, and particularly arranged marriage. However, their risk is heightened in the case of family breakdown (due to divorce, violence or parental death) as well as in contexts where boys have limited opportunities to inherit agricultural land, where livelihood opportunities are not linked to education levels (for example, khat production), and where adolescent-initiated marriage is the only way to assert an 'adult' identity.

\section{Implications for Policy and Practice}

The implications of the article's findings for policy and practice are severalfold. First, our focus on both arranged and adolescent-initiated marriages suggest that progress towards SDG target 5.3 which calls for the elimination of child marriage by 2030 will necessitate more context-tailored approaches (as also argued by Cislaghi et al. 2019). Efforts need to go beyond a focus on interventions to raise awareness about the risks of child marriage (which have been found to have limited traction, e.g. Pankhurst et al. 2016; Santelli et al. 2018), and simultaneously invest in programming that expands adolescents' collective capabilities, including enhancing reporting on and enforcement of legal prohibitions (including sanctions against child marriage in the Ethiopian Family Code), and improving access to opportunities for education and economic advancement (e.g. Raj et al. 2019) such as social protection support for secondary school attendance, skills building and vocational counselling in line with SDG 1 on social protection and SDG 8 on decent work (given the close association between child marriage and poverty) and adolescent life-skills programming to enhance knowledge about their rights, dismantle discriminatory gender norms and augment their voice and agency. Exposure, especially for girls, to role models who have resisted powerful community 'gatekeepers' (e.g. parents, religious leaders, community elders) to follow alternative pathways is also key.

Second, our findings also call for greater engagement with boys and young men (both as those who are vulnerable to child marriage as well as co-perpetrators with parents and wider communities) in line with the African Charter on the Rights and Welfare of the Child and its call to eliminate the risk of betrothal and marriage facing both girls and boys. Programming for adolescent boys could draw on lessons from recent initiatives to shift harmful conceptualisations of masculinity and 
promote context-tailored opportunities to critically examine models of masculinity, to reflect, and to explore new ways of being and 'doing manhood' in their daily interactions with their partners, families and friends, including Addis Birhan and Male Norms Initiatives, both in Ethiopia (see Marcus 2018).

\section{Limitations}

Whilst our research sample encompasses two distinct socio-cultural and geographic regions of Ethiopia and can illustrate some of the complexities of gender and social norms surrounding different forms of child marriage, there are 10 regions in Ethiopia and thus we are only able to capture some of the country's diversity. Contexttailored programming efforts will require analogous in-depth research in other locations, as well as with a wider set of potentially influential actors including 'outliers', i.e. young adults from analogous communities who have defied dominant social norms to resist pressures from community gatekeepers to marry as children so as to better understand what supports are needed to encourage alternatives to marriage and early parenthood.

\section{Conclusion}

Overall this article has underscored that if the rights and welfare of all children are to be realised, including the eradication of child marriage in line with SDG target 5.3 , it is critical to employ a lens that is both gendered and context-specific. Our findings show that in the Ethiopian context adolescent experiences of child marriage are shaped by gender, age and inheritance practices, and are mediated at meso and macro levels through social norms, the availability of basic services (especially secondary schools), and policy and legal frameworks not only around age of marriage but also those that advance adolescents' collective capabilities, such as investments in adolescent/youth skills building and age- and gender-responsive social protection. Whilst adolescent girls, especially very young girls, are at greater risk of child marriage and truncated opportunities to develop their full educational and economic capabilities, some boys are also at risk, especially following parental death or divorce, as well as due to limited livelihood alternatives. Moreover, adolescents may face risks not only from marriages arranged by parents, but also from socio-cultural milieus where adolescent-initiated marriages are perceived as the only option to exercise agency due to a dearth of alternative lifepath options. These complex and intersecting vulnerabilities need to be considered within efforts to combat the practice and support the realisation of adolescents' full individual and collective capabilities.

\section{Declarations}

Conflict of interest On behalf of all authors, the corresponding author states that there is no conflict of interest. 
Open Access This article is licensed under a Creative Commons Attribution 4.0 International License, which permits use, sharing, adaptation, distribution and reproduction in any medium or format, as long as you give appropriate credit to the original author(s) and the source, provide a link to the Creative Commons licence, and indicate if changes were made. The images or other third party material in this article are included in the article's Creative Commons licence, unless indicated otherwise in a credit line to the material. If material is not included in the article's Creative Commons licence and your intended use is not permitted by statutory regulation or exceeds the permitted use, you will need to obtain permission directly from the copyright holder. To view a copy of this licence, visit http://creativecommons.org/licen ses/by/4.0/.

\section{References}

Amoo, E.O., A. Igbinoba, D. Imhonopi, O.O. Banjo, C.K. Ajaero, J.O. Akinyemi, D. Igbokwe, and L.B. Solanke. 2018. Trends, determinants and health risks of adolescent fatherhood in Sub-Saharan Africa. Ethiopian Journal of Health Sciences 28 (4): 433-442. https://doi.org/10.4314/ejhs.v28i4.9.

Arthur, M., A. Earle, A. Raub, I. Vincent, E. Atabay, I. Latz, G. Kranz, A. Nandi, and J. Heymann. 2018. Child marriage laws around the world: Minimum marriage age, legal exceptions, and gender disparities. Journal of Women, Politics and Policy 39 (1): 51-74. https://doi.org/10.1080/1554477X.2017.1375786.

Bankole, A., A. Biddlecom, G. Guiella, S. Singh, and E. Zulu. 2007. Sexual behavior, knowledge and information sources of very young adolescents in four Sub-Saharan African countries. African Journal of Reproductive Health/la Revue Africaine De La Santé Reproductive 11 (3): 28-43. https://doi.org/10. 2307/25549730.

Biswas, S.C., S. Karim, and S.F. Rashid. 2020. Should we care: A qualitative exploration of the factors that influence the decision of early marriage among young men in urban slums of Bangladesh. British Medical Journal Open 2020 (10): e039195. https://doi.org/10.1136/bmjopen-2020-039195.

Boyden, J., A. Pankhurst, and Y. Tafere. 2013. Harmful traditional practices and child protection: Contested understandings and practices of female child marriage and circumcision in Ethiopia. Working Paper 93. Oxford: Young Lives.

Central Statistical Agency (CSA) and ICF. 2017. Ethiopia Demographic and Health Survey 2016. Addis Ababa and Rockville: CSA and ICF.

CSA. 2013. Population projections for Ethiopia 2007-2037. Addis Ababa: CSA.

Cislaghi, B., G. Mackie, P. Nkwi, and H. Shakya. 2019. Social norms and child marriage in Cameroon: An application of the theory of normative spectrum. Global Public Health 14 (10): 1479-1494.

Clark, S., J. Bruce, and A. Dude. 2006. Protecting young women from HIV/AIDS: The case against child and adolescent marriage. International Family Planning Perspectives 32 (2): 79-88.

Connell, R.W. 2003. The Role of Men and Boys in Achieving Gender Equality. United Nations Development Programme (UNDP) Expert Group Meeting. 21 to 24 October, Brasilia.

Connell, R.W., and J.W. Messerschmidt. 2005. Hegemonic masculinity: Rethinking the concept. Gender and Society 19 (6): 829-859.

O'Brien, B.C., I.B. Harris, T.J. Beckman, D.A. Reed, and D.A. Cook. 2014. Standards for reporting qualitative research: a synthesis of recommendations. Academic Medicine 89 (9): 1245-1251. https://doi.org/ 10.1097/ACM.0000000000000388.

de Groot, R., M.Y. Kuunyem, T. Palermo, and Ghana LEAP 1000 Evaluation Team. 2018. Child marriage and associated outcomes in northern Ghana: A cross-sectional study. BMC Public Health 18 (1): 285. https://doi.org/10.1186/s12889-018-5166-6.

Emirie, G., M. Getu, and K. Habtamu. 2017. Prevalence, drivers and protective factors of early marriage in Amhara, Oromia and SNNP regions of Ethiopia. Research Report. Addis Ababa: Plan International and Ethiopian Society of Sociologists, Social Workers and Anthropologists (ESSSWA).

Erulkar, A.S., and E. Muthengi. 2009. Evaluation of Berhane Hewan: A program to delay child marriage in rural Ethiopia. International Perspectives on Sexual and Reproductive Health 35 (1): 6-14. https://doi. org/10.1363/ifpp.35.006.09.

Erulkar, A., A. Ferede, W. Ambelu, W. Girma, H. Amdemikael, B. GebreMedhin, B. Legesse, A. Tameru, and M. Teferi. 2010. Ethiopia gender survey: A study in seven regions. Addis Ababa: Population Council.

GAGE Consortium. 2019. Gender and adolescence: Why understanding adolescent capabilities, change strategies and contexts matters, 2nd edn. London: Gender and Adolescence: Global Evidence. https:// 
www.gage.odi.org/wp-content/uploads/2020/01/Conceptual-Framework-2nd-Edition_WEB.pdf. Accessed 30 April.

Gaston, C., C. Misunas, and C. Cappa. 2019. Child marriage among boys: A global overview of available data. Vulnerable Children in the Youth Studies 14 (3): 219-228.

George, A.S., A. Avni, C.M. de Abreu Lopes, and T.K.S. Ravindran. 2020. Structural determinants of gender inequality: Why they matter for adolescent girls' sexual and reproductive health. BMJ 368: 16985. https://doi.org/10.1136/bmj.16985.

Girls Not Brides. 2017. Child marriage and maternal health: An information sheet. https://www.girlsnotbr ides.org/wp-content/uploads/2017/06/Child-marriage-and-maternal-health-Girls-Not-Brides-June2017.pdf. Accessed 30 April.

Harper, C., N. Jones, A. Ghimire, R. Marcus, and G.K. Bantebya (eds.). 2018. Empowering Adolescent Girls in Developing Countries. Gender Justice and Norm Change. Oxford: Routledge.

Ibrahim, S. 2006. From individual to collective capabilities: The capability approach as a conceptual framework for self-help. Journal of Human Development 7 (3): 397-416. https://doi.org/10.1080/14649 880600815982.

Jones, N., B. Tefera, J. Stephenson, T. Gupta, P. Pereznieto, G. Emirie, B. Gebre, and K. Gezhegne. 2014. Early marriage and education: The complex role of social norms in shaping Ethiopian adolescent girls' lives. London: Overseas Development Institute.

Jones, N., G. Emirie, B. Tefera, and E. Presler-Marshall. 2016a. Surprising trends in child marriage in Ethiopia. Briefing Paper. London: UNICEF and Overseas Development Institute.

Jones, N., B. Tefera, G. Emirie, B. Gebre, K. Berhanu, E. Presler-Marshall, D. Walker, T. Gupta, and G. Plank. 2016b. One size does not fit all: The patterning and drivers of child marriage in Ethiopia's hotspot districts. London: UNICEF and Overseas Development Institute.

Jones, N., B. Tefera, G. Emirie, and E. Presler-Marshall. 2018. 'Sticky' gendered norms: Change and stasis in the patterning of child marriage in Amhara, Ethiopia. In Empowering adolescent girls in developing countries: Gender justice and norm change, eds., C. Harper, N. Jones, A. Ghimire, R. Marcus and G. Kyomuhendo Bantebya, xx. London: Routledge.

Jones, N., S. Baird, and L. Lunin. 2018b. GAGE research design, sample and methodology. London: Gender and Adolescence: Global Evidence.

Kidman, R. 2016. Child marriage and intimate partner violence: A comparative study of 34 countries. International Journal of Epidemiology 46 (2): 662-675. https://doi.org/10.1093/ije/dyw225.

le Roux, E., B.E. Bartelink, and S. Palm. 2017. What is the harm in 'harmful traditional practices'? Policy Brief. https://assets.publishing.service.gov.uk/media/5c7d541e40f0b603d7852921/PB_What_is_the_ harm_S02_18Dec17.pdf. Last accessed 30 April.

Marcus, R. 2018. Programming to promote gender-equitable masculinities among adolescent boys: key findings from a rigorous review. London: Gender and Adolescence: Global Evidence.

Messerschmidt, J.W. 2019. The salience of "hegemonic masculinity". Men and Masculinities 22 (1): 85-91. https://doi.org/10.1177/1097184X18805555.

Ministry of Women, Children and Youth. 2019. National costed roadmap to end child marriage and FGM/C 2020-2024. Addis Ababa: Ministry of Women, Children and Youth. https://www.unicef.org/ethiopia/ reports/national-costed-roadmap-end-child-marriage-and-fgmc-ethiopia. Last accessed 30 April

Muthengi Karei, E., and A. Erulkar. 2010. Building programs to address child marriage: The Berhane Hewan experience in Ethiopia. New York: United Nations Population Fund (UNFPA).

Nussbaum, M. 2011. Creating capabilities: The human development approach. Cambridge: Harvard University Press.

Pankhurst, A., A. Tiumelissan, and N. Chuta. 2016. The interplay between community, household and child level influences on trajectories to early marriage in Ethiopia: Evidence from Young Lives. Oxford: Young Lives.

Raj, A. 2010. When the mother is a child: The impact of child marriage on the health and human rights of girls. Archives of Disease in Childhood 95 (11): 931-935.

Raj, A., M. Salazar, E.C. Jackson, et al. 2019. Students and brides: A qualitative analysis of the relationship between girls' education and early marriage in Ethiopia and India. BMC Public Health 19: 19. https:// doi.org/10.1186/s12889-018-6340-6.

Rauschmayer, F., C. Polzin, M. Mock, and I. Omann. 2018. Examining collective action through the capability approach: The example of community currencies. Journal of Human Development and Capabilities 19 (3): 345-364. 
Santelli, J.S., E. Spindler, E. Moore, and T. McGovern. 2018. Criminalising sexuality or preventing child marriage: Legal interventions and girls' empowerment. The Lancet Child and Adolescent Health 3 (4): 206-208. https://doi.org/10.1016/S2352-4642(18)30370-5.

Sen, A.K. 2008. The idea of justice. Journal of Human Development 9 (3): 331-342.

Stewart, F. 2005. Groups and capabilities. Journal of Human Development 6 (2): 185-204.

UNICEF. 2018. Ending child marriage: A profile of progress in Ethiopia. New York: UNICEF.

UNICEF Regional Office in South Asia. 2018. Key drivers of the changing prevalence of child marriage in three countries in South Asia. Kathmandu: UNICEF Regional Office in South Asia. https://www. unicef.org/rosa/sites/unicef.org.rosa/files/2018-08/KEY\%20DRIVERS\%20changing\%20prevalance\% 20of\%20child\%20marriage.pdf. Last accessed 30 April.

Wodon, Q., C. Male, A. Nauihouba, A. Onagoruwa, A. Savadogo, A. Yedan, A. Kes, N. John, M. Steinhaus, L. Murithi, J. Edmeades, and S. Petroni. 2018. Economic impacts of child marriage in Ethiopia: Synthesis Report. Washington, DC: The World Bank and International Center for Research on Women.

Yaya, S., E.K. Odusina, and G. Bishwajit. 2019. Prevalence of child marriage and its impact on fertility outcomes in 34 sub-Saharan African countries. BMC International Health and Human Rights 19: 33. https://doi.org/10.1186/s12914-019-0219-1.

Publisher's Note Springer Nature remains neutral with regard to jurisdictional claims in published maps and institutional affiliations. 